\title{
IDENTIFIKASI KEASLIAN KARYA SENI RUPA DENGAN TEKNOLOGI IMAGE PROCESSING BERDASARKAN DETEKSI WARNA DAN TEKSTUR
}

\author{
Ari Purno Wahyu W ${ }^{\mathbf{1}}$, Kaffah Imanuddin M R Santosa ${ }^{2}$ \\ ${ }^{1)}$ Fakultas Teknik Informatika, Universitas Widyatama \\ ${ }^{2)}$ Desain Komunikasi Visual, Sekolah Tinggi Teknologi Bandung \\ Jl. Cikutra No.204A, Sukapada, Cibeunying Kidul, Kota Bandung \\ ari.purno@widyatama.ac.id ${ }^{1}$, kaffahimrs@gmail.com ${ }^{2}$
}

\begin{abstract}
AbTSRAK
Sebuah karya merupakan hasil buah pikiran seseorang dalam menciptakan sebuah bentuk benda atau seni rupa, karya tersebut tidak hanya subuah benda dan bisa dalam bentuk ide kreatif dan edukasi yang berguna bagi kehidupan masyarakat, pada perkembangan dunia digital saat ini memiliki sebuah dampak-dampak positif dan negatif, sebagai contoh seseorang dapat dengan mudah mengambil karya seni rupa orang lain tanpa adanya credit atau pemberian izin dari kekayaan intelektual atau HAKI, tetapi hal ini tidak masalah jika bentuk seni rupa tersebut dibebaskan oleh pembuat seni rupa dan boleh untuk disebarluaskan, untuk mengatasi masalah pemalsuan karya seni tersebut dibuatlah sistem indentifikasi karya seni rupa berbasis image prosessing, dengan sistem identifikasi ini pengenalan karya seni rupa bisa dengan cara identifikasi tekstur yang secara detail bisa membaca bagian-bagian terpenting dari lukisan atau karya seni rupa tersebut dengan membaca pixel dan komposisi warna.
\end{abstract}

Kata kunci: seni rupa, image processing, analisa warna, analisa tekstur

\section{Abstract}

A work of art is a result of someone's thoughts in creating a form of object or art, the work is not just an object and can be in the form of creative ideas and educational concepts that are useful for human lives, the development of the digital world today has a positive impact and negative, for example someone can easily take other people's art works or ideas without credit or granting permission from intellectual property or intellectual property rights, but this does not matter if the art form is released by the art maker and is allowed to be distributed, to overcome With this identification system, the identification of works of art can be done by identifying textures, which in detail can read the most important parts of the painting or work of art by reading pixels and text. color position.

Keywords: fine art, image processing, color analysis, texture analysis

\section{PENDAHULUAN}

Identifikasi keaslian dari sebuh produk sangatlah penting, hal ini berguna untuk menjaga sebuah proses kekayaan intelektual terutama pada barang seni rupa. Barang seni memiliki nilai yang tinggi dan seringkali dipalsukan oleh pihak yang tidak bertangguang jawab, untuk menjaga hal tersebut beberapa barang seni rupa sudah di indentifikasi menggunakan barcode dan data ID. Data tersebut bisa dipergunakan sementara sebagai pembuktian bahwa barang tersebut asli, metode lain dalam mendeteksi barang seni rupa adalah dengan menggunakan teknik image processing berbasis komputer vision (open CV). Metode ini membaca sebuah kode unik melalui pembacaan warna serta tekstur pada barang seni rupa tersebut. Teknik pemalsuan yang tinggi akan membuat sebuah objek dibuat menjadi semirip mungkin dengan bantuan teknologi, tetapi dengan deteksi komputer vision, proses pemalusauan akan terbaca dengan cara membaca kode warna serta kerapatan dari sebuah pixel. Data dari pixel tersebut kemudian di visualisasikan dengan angka sehingga perbandingan antara barang seni rupa yang asli atau dipalsukan bisa didata melalui kode warna dan kerapatan pixel.

\section{LANDASAN TEORI}

Pada umumnya untuk mendeteksi sebuah objek atau benda bisa dengan mudah menggunakan ID atau 
kode identitas, kode ini biasanya dibuat dalam bentuk barcode sehingga kondisi serta asal dari produk tersebut bisa untuk dilacak, dengan kata lain jika sebuah produk memiliki sebuah data identitas maka akan dipastikan produk tersebut memiliki kualitas yang bagus dan bisa dijamin keasliannya. Pengambilan data ID bisa menggunakan tampilan objek visual atau menggunakan bantuan kamera yang bersifat mobile, kamera sendiri digunakan karena bisa mendeteksi sebuah objek dalam bentuk 2D dan 3D sehingga dijadikan sebuah patokan dasar untuk mendeteksi karakteristik terhadap identitas suatu produk (Matthias Blankenburga; Christian Hornb ; J"org Kr"ugera, 2015).

Identifikasi secara visual terhadap karekteristik suatu produk menjadi sebuah tools yang kuat dan bisa dikembangkan pada banyak aplikasi, sebagia contoh ciri sebuah tanda tangan akan dii dentifikasi melalui strukturnya, sehingga perubahan ukuran atau bentuk tandatangan tidak bisa dipalsukan walaupun dibuat semirip mungkin dengan objek aslinya (Xu Y, Ji H, Ferm“uller C., 2009).

Sebagai seorang peneliti yang jeli kita perlu menggunakan sebuah alat bantu untuk mendeteksi sebuah produk dengan kata lain secara komputerisasi, teknik tersebut adalah dengan bantuan komputer vision. Metode komputer ini mampu menyajikan sebuah data dan merubahnya kedalam sebuah bentuk bilangan biner, setiap data gambar saat dibaca oleh teknik komputer vision akan memliki bentuk yang berbeda yang dilihaat dari kepadatan warna dan jenis variasi data yang berbeda yang membedakan objek yang sama tetapi tidak serupa (Tuceryan M, Jain AK., 2001).

Untuk mengambil sebuah objek bisa langsung menggunakan bantuan kamera 3D dasar dari pengambilan gambar 3D dimensi ini adalah triangular objects atau objek bisa dibaca dari tiga sudut yang berbeda, objek ini dengan mudah diambil dengan meggunakan perangkat mobile, setiap objek yang diambil tentu memiliki bentuk serta pencahayaan yang berbeda yang dipengaruhi oleh jarak pengambilan objek dan faktor lingkungan (B., 2005).

Deteksi bentuk berarti mengubah sebuah pola warna menjadi sebuah pixel yang bisa teridentifikasi menjadi beberapa bagian dan disajikan dalam sebuah pola bentuk pola arimatika, sebagai contoh pendekatan pembacaan data 3D bisa ditampikan dan diproses dengan metode Harris dan SIFT algoritma (Sipiran I and Bustos B, 2010)

Pada sebuah proses deteksi objek diperlukan dua tahapan penting yaitu ektrasksi bentuk dan pecocokan pola, ektraksi bentuk berfungsi untuk mendeteksi sebuah pola unik dari objek yang diambil, proses identifikasi akan membaca sebuah pola unik dan feature vector, pada pecocokan dilakukan untuk memproses sebuah kode unik yang ditargetkan pada data pixel, proses ini akan membandingkan objek yang dibaca dengan objek yang lain hingga mencapai batas akurasi pembacaan sebuah data untuk mencari nilai akurasi tertinggi (Somaraju Boda., 2009).

Warna menjadi sebuah feature yang menarik yang bisa pergunakan untuk mendeteksi objek, warna sendiri mempunyai nilai properti yang unik yang bisa mengambarkan ketebalan dari sebuah objek bisa mempermudah pada saat proses pengenalan sebuah pola (Arun Priya C, Balasaravanan T, Thanamani A, 2012).

Proses pengambilan sebuah objek akan terkendala oleh faktor pencahayaan atau bahkan latar belakang pada saat objek itu diambil, proses analisa ini akan lebih mudah jika kombinasikan dengan teknik machine learning. metode ini akan membaca sebuah objek utama dan memisahkan objek dari background, proses ini menjadi sebuah bagian penting sebelum objek tersebut terdeteksi dan bisa meningkatkan nilai akurasi (Ibaphyrnaishisha Kharir, Vikaho Z Swu, Dibya Jyoti Bora, 2020).

\section{METODE DAN PENELITIAN}

Pada metode penelitian ini sistem identifikasi barang seni rupa untuk melihat asli atau tidak mengguanakan dua tahapan pengujian, sistem pengujian tersebut menggunakan sebuah teknik identifiksi bentuk dan warna, kedua metode ini memiliki beberapa tahapan yaitu bentuk untuk identifikasi barang berupa patung, sedangkan identifikasi warna untuk barang seni rupa berupa lukisan dalam bentuk gambar lainnya, tahapan proses image processing tersebut adalah sebagai berikut:

- Proses input

Pada sistem ini akan dilakukan sebuah proses identifikasi inputan benda atau objek dengan dalam bentuk gambar, pada proses input tersebut data yang diambil akan memiliki jumlah dan bentuk pixel yang 
berbeda dikarenakan proses pengambilan gambar yang bervariasi serta kondisi tempat pengambilan gambar yang memilki tingkat pecahayaan yang berbeda-beda.

- Deteksi bentuk

Pada metode dipergunakan pengujian bentuk pada barang seni rupa yang berfungsi melakukan proses identifiaksi corak dan warna, dari bentuk tersebut sistem atau aplikasi bisa membaca pola unik dari barang seni rupa yang akan di identifikasi.

- Deteksi warna

Pada metode ini proses deteksi warna untuk membaca jenis warna yang ada pada barang seni rupa, metode ini akan mengkonversi kedalam bentuk RGB (Reg, Green, blue), data komposisi warna tersebut kemudian dikonversikan kedalam bentuk bilangan biner, data biner kemudian mampu membaca dan membedakan barang tersebut dipalsukan atau tidak, sebagia contoh lukisan yang dipalsukan akan memiliki kode warna yang berbeda dengan objek yang asli yang tidak bisa dibedakan secara langsung secara kasat mata.

- Deteksi tekstur

Pada metode ini berfungsi membaca data dari barang seni rupa karena mempunyai bentuk dan ukuran yang unik, tekstur ini bisa dipergunakan untuk membedakan barang seni rupa berupa batik atau jenis seni rupa yang memiliki corak berbebeda.

- Indentifikasi hasil akhir

Pada proses indentifikasi merupakan sebuah respon akhir dari pembuatan aplikasi, program deteksi bisa dibuat dalam bentuk konsol atau menggunakan aplikasi GUI (Graphical User Interface) pada aplikasi console dipergunakan untuk mendeteksi atau melakukan proses ujicoba pada koding program sedangkan GUI biasanya aplikasi yang dipergunakan dan diperuntukan untuk kalayak umum.

Pada implementasi ini penulis menggunakan bahasa pemograman $\mathrm{c}$ dan $\mathrm{c}++$ karena bahasa pemograman ini memiliki modul yang bisa dipergunakan untuk mengolah data dalam bentuk image processing.

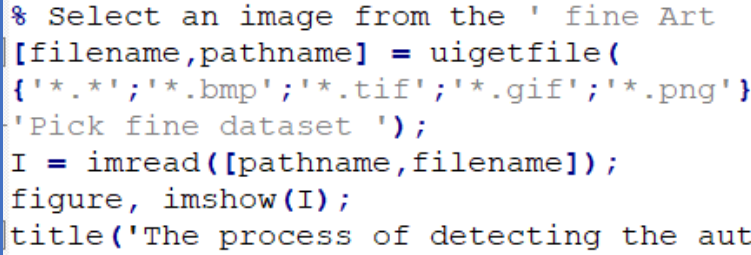

Gambar 1. Kode Program proses inputan data

Pada gambar 1 diatas adalah kode program yang dipergunakan untuk memproses sebuh inputan data yang dalam bentuk gambar, gambar tersebut bisa diambil langsung melalui samrtphone atau diunduh langsung melalui internet, data gambar yang diambil kemudian dikonversi kedalam beberapa format, yaitu format BMP, Tif, gif dan Png., setiap data bisa langsung diproses atau sistem menyediakan sebuah dataset lengkap dalam bentuk folder yang telah dibuat dengan menu [pathname,filename], yang dimaksud dengan kode tersebut penggunana aplikasi bisa mempergunakan menu yang ada pada dataset atau langsung memproses gambar pada saat awal gambar diambil.

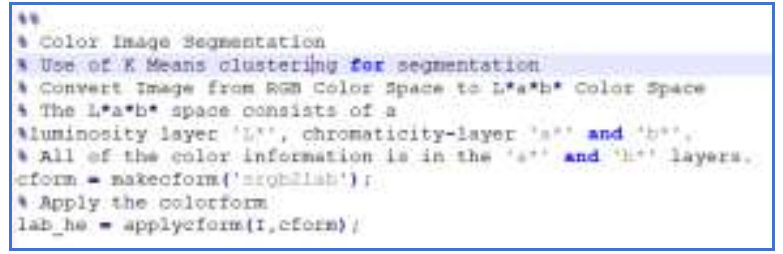

Gambar 2. Proses identifikasi warna

Pada gambar 2 diatas adalah sebuah proses segmentasi warna, proses segmentasi ini berguna pada saat pemrosesan gambar seni rupa dalam bentuk lukisan, pada proses segmentasi tersebut konvesi warna dari RGB dan $L^{*} a * b$

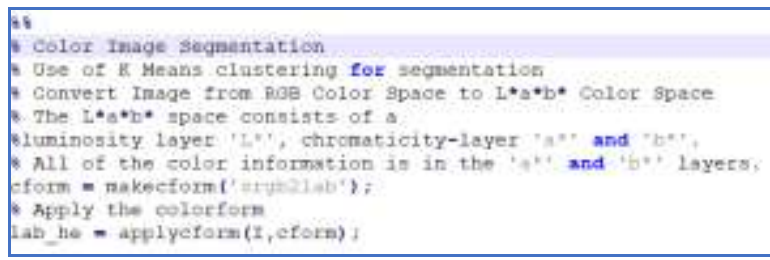

Gambar 3. Proses pemisahan warna

Pada gambar 3 diatas adalah sebuah proses segmentasi dan pemisahan warna, warna tersebut akan ditampilkan dalam betuk visual dan grafik warna yang secara tidak langsung bisa dipergunakan membaca objek yang asli atau yang palsu. 


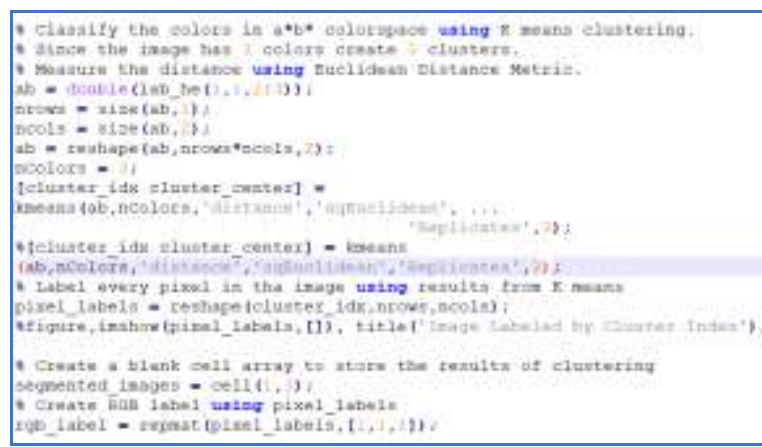

Gambar 4. Proses klasifiksai warna dengan $K$ Mean

Pada gambar 4 diatas adalah sebuah proses dan hasil klasifikasi pada kode warna menggunakan $k$ mean algorithm yang nantinya akan diidentifikasi menjadi beberapa bagian, algoritma tersebut berguna membaca data unik dari ketajaman warna yang tidak bisa identifikasi dengan algoritma yang lain.

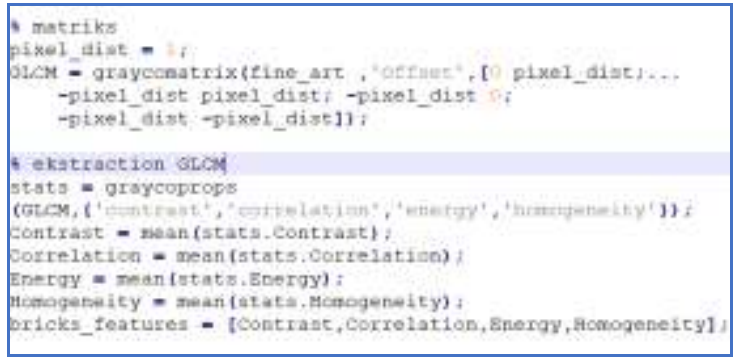

Gambar 5. Proses klasifikasi dengan data matrik

Pada gambar 5 diatas adalah sebuah proses perhitungan matrik dari objek yang akan direcognisi menggunakan teknik image processing, pada sistem deteksi diatas menggunakan sistem deteksi bentuk dengan metode GLCM (Gray-Level Co-Occurrence Matrix.

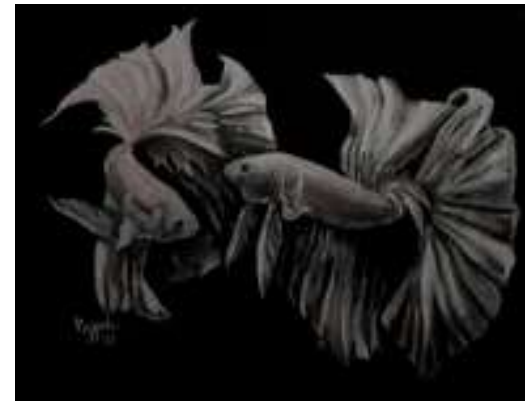

Gambar 6. Data sample dengan objek lukiasan
Pada gambar 6 diatas adalah contoh seni rupa dalam bentuk lukisan yang akan diidentifikasi fitur unik dari lukisan yang asli dengan membaca fitur resmi dari RGB atau komposisi warna dan tekstur dengan menggunakan metode GLCM.

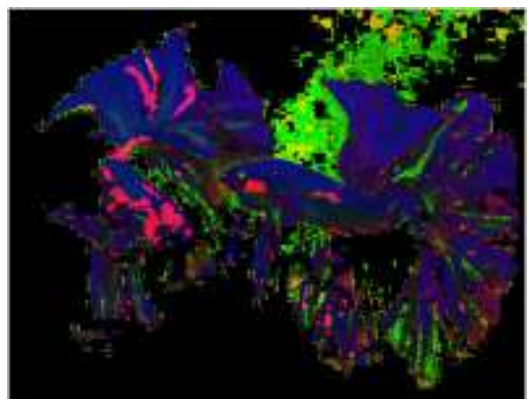

Gambar 7. Konversi dengan format warna

Pada gambar diatas adalah proses pembacaan pada kedalam sebuah format warna, objek yang berbentuk hitam putih akan memiliki nilai dan komposisi warna RGB yang bisa dipergunakan untuk menghitung jenis format warna RGB, data format warna RGB tersebut akan ditampilkan dalam bentuk angka dan disajikan secara visual sehingga perbedaan dari lukisan yang asli dan dipalsukan akan mudah di identifikasi.

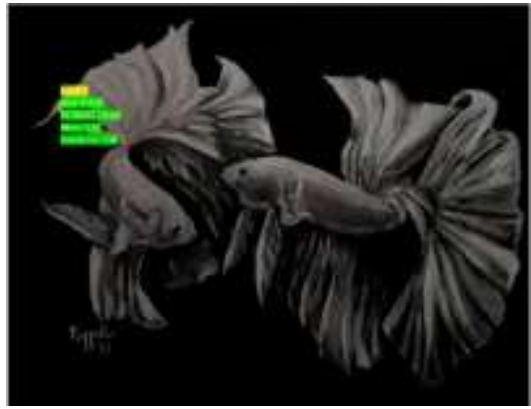

Gambar 8. Identifikasi tekstur

Pada gambar 8 diatas adalah sebuah proses identifikasi tekstur dan unik dari setiap bentuk dari seni rupa yang dibuat, alagoritma $k$-Mean akan melakukan proses identifikasi dari setiap tekstur yang dibaca pada setiap bagian. 


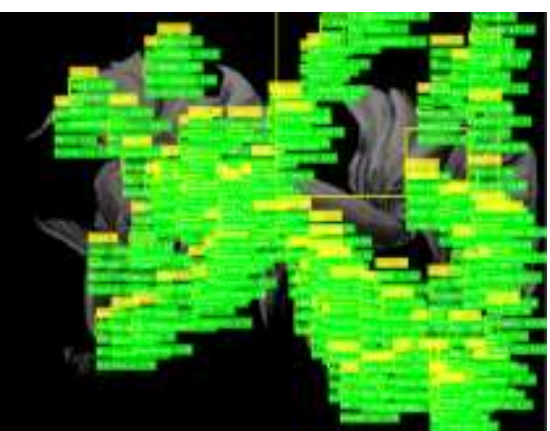

Gambar 9. Proses Marking data

Pada gambar 9 diatas ditampilkan sebuah marking data dari pembacaan sistem identifikasi fitur unik dari lukisan, dari fitur unik tersebut algoritma menampilkan nilai visual dan memberi tanda serta kode area dengan proses scanning fitur unik pada objek hingga 196 kali proses scan data, semakin banyak proses scanning maka fitur unik pada objek tersebut semakin banyak identifikasi dan menjadi fitur objek yang unik.

\section{IV .KESIMPULAN DAN SARAN}

Pada implementasi identifikasi objek dengan image processing dapat dengan mudah diimplementasikan, pada saat pengujain teknik image prosessing akan melakukan proses identifikasi dan pembacaan data hingga 198 kali untuk satu jenis karya, sistem identifikasi dibagi menjadi beberapa bagian yaitu identifikasi warna dan bentuk, warna dipergunakan untuk menampilkan jumlah komposisi warna dengan menggunakan pixel dan bentuk dengan menggunakan metode Gray Level Co-occurrence Matrix (GLCM) dengan akurasi pembacaan hingga $80 \%$, sistem GLCM ini berguna untuk mengindentikasi karya seni rupa dalam bentuk patung atau lukisan.

\section{REFERENSI}

Arun Priya C, Balasaravanan T, Thanamani A. (2012). An efficient leaf recognition algorithm for plant classification using support vector machine. informatics and medical engineering (PRIME), 428-432.

B., J. (2005). Digital Image Processing. Heidelberg: Springer.

Ibaphyrnaishisha Kharir, Vikaho Z Swu, Dibya Jyoti Bora. (2020). Identification of Different Plants through
Image Processing Using Different Machine Learning Algorithms. ISSN: 2249-6661.

Matthias Blankenburga; Christian Hornb ; J"org Kr"ugera . (2015). Detection of counterfeit by the usage of product inherent features . ScienceDirect, $430-$ 435 .

Sipiran I and Bustos B. (2010). A Robust 3D Interest Points Detector Based on Harris Operator. Proc. EUROGRAPHICS Workshop on $3 D$ Object Retrieval.

Somaraju Boda. (2009). Feature-Based Image Registration. Rourkela: National Institue of Technology.

Tuceryan M, Jain AK. (2001). Tuceryan M, Jain AK. Texture Analysis, Handbook of Pattern Recognition \& Computer Vision . 2nd ed.: World Scientifc Publishing Co. Ptc. Ltd. .

Xu Y, Ji H, Fermüuller C. (2009). Viewpoint Invariant Texture Description Using Fractal Analysis. Int J Comput Vision, 85-100.

Ari Purno Wahyu W, Kaffah Imanuddin M R Santosa 